\title{
The Analysis of Location Selection of Shandong Province Manufacturing Enterprises Direct Investment in Countries Along the Belt and Road
}

\author{
Pei-Zhi Wang ${ }^{1, a}$, Shu-Yue Zhang ${ }^{2, b}$ and Zhe-Ning $\mathrm{Yu}^{3, \mathrm{c}}$ \\ ${ }^{123}$ Shandong University of Finance and Economics, Jinan, China \\ awpzmail@126.com, bzsy1994m@163.com, ${ }^{\mathrm{c}}$ ljxyzn@163.com
}

Keywords: "The Belt and Road" initiative, Foreign direct investment, Cultural distance, Investment motivation.

\begin{abstract}
In this paper, we use logit analysis of the panel data of the direct investment of manufacturing enterprises above designated size in Shandong Province in countries along the "Belt and Road" from 2009 to 2013, test the location selection and influencing factors of manufacturing enterprises above designated size in Shandong Province for direct investment in countries along " the Belt and Road". The results show that the manufacturing enterprises in Shandong Province's OFDI have the resource seeking and strategic asset seeking motivation in countries along "the Belt and Road", the economic scale of Shandong Province will promote enterprises' OFDI in the province and the cultural distance hinders the OFDI of the enterprises in Shandong Province, larger countries have a positive effect on the OFDI in Shandong Province only if they have abundant natural resources, and their previous investment experience helps to the investment in the future.
\end{abstract}

\section{Introduction}

With the acceleration of economic globalization, OFDI in China has shown a trend of rapid growth. At present, "the Belt and Road" construction in our country has also entered a new phase of full and pragmatic cooperation and investment and cooperation with other countries along the regions have been further deepened. As one of the earliest provinces in China to carry out direct foreign investment, Shandong Province has enjoyed rapid and sustained growth in investment in recent years and accumulated rich experience in foreign investment. According to data from Shandong Provincial Department of Commerce, the actual foreign investment in Shandong Province in 2017 reached 37.77 billion yuan, an increase of 9.3\%; new progress was made in cross-border mergers and acquisitions, with an actual investment of 11.78 billion yuan, accounting for a total of $31.2 \%$. On the other hand, the Shandong provincial government responded positively to " the Belt and Road" construction and further increased the proportion of its overseas investment. In 2017, the actual investment in the countries along " the Belt and Road" reached 10.06 billion yuan, an increase of 81.7 percentage points, accounting for $26.7 \%$ of the province, up $20.3 \%$ over the same period of last year. However, as the enterprises in Shandong Province continue to expand their direct investment in the regions along " the Belt and Road", the risks they face in the investment process have become increasingly prominent. How to reduce or even avoid the Shandong enterprises' investment risks in the countries along the routes is appropriate, and the location choice analysis has important research value.

\section{Literature Review}

In the existing research, they mainly analyze the OFDI location selection and its influencing factors along " the Belt and Road" from the national level. Based on the gravity model, Zhang Yabin (2016) uses the principal component analysis of means to measure the level of investment facilitation along the regions, and analyze its impact on China's OFDI; Chen Weiguang etc.(2016) and Cui Riming etc.(2017) estimate China's potential for investment along " the Belt and Road" and make recommendations based on different investment locations; Guo Yexy(2016), Chen Yinmo et al. (2017) and Zhao Mingliang (2017) respectively examined the relationship between bilateral high-level meetings, the number of Confucius Institutes and international investment risks with 
China's direct investment in countries along " the Belt and Road"; according to the research, Zhang Shoucun (2017) thought that China has taken into consideration the characteristics of regional differences in OFDI along " the Belt and Road" and proposed the basic idea of optimizing the layout of investment. However, there are almost no relevant researches on OFDI in Shandong Province, especially there are few related researches at the enterprise level. Therefore, this paper based on the panel data of the direct investment of manufacturing enterprises above designated size in Shandong Province in the countries along "the Belt and Road" from 2009 to 2013 to test the location selection and influencing factors of manufacturing enterprises in Shandong Province to direct investment along the region and to put forward reasonable policy suggestions.

\section{Theoretical Hypotheses}

\section{The Motivation of Resources Seeking}

Resource seeking is one of the most important motivations of outward investment, driven by the search for natural resources such as fuel, minerals and metals. On the one hand, resource-rich countries often lack capital, management experience and advanced technologies and need to rely on investment from other countries for development. On the other hand, China, as a world factory, inevitably faces the problem of scarcity of resources while foreign direct investment the effective way of resources, the two have strong complementarity. To test the motivation of manufacturing enterprises in Shandong Province to seek the resources of OFDI in the countries along " the Belt and Road", there is a hypothetical 1.

Hypothesis 1: The host country's reserve of natural resources is proportional to the OFDI of the manufacturing enterprises in Shandong Province to countries along " the Belt and Road".

\section{The Motivation of Strategic Assets Seeking}

Strategic assets refer to the resources and capabilities possessed by enterprises that are of decisive value to the formation and development of competitive advantages (Li Qiang, 2011), such as technology, brand and management experience. As strategic assets cannot be purchased through the traditional factor market and are cultivated slowly, with greater uncertainty and higher demands on the external environment, enterprises usually obtain strategic assets through OFDI in order to continuously enhance their competitive advantages. In particular, Cross-border M \& A is an effective way for enterprises to quickly acquire strategic assets (Deng, 2003).

Hypothesis 2: The strategic assets of the host country are in direct proportion to the OFDIs of the manufacturing enterprises in Shandong Province to countries along " the Belt and Road".

\section{Cultural Distance}

Cultural distance refers to the difference between the norms and values enjoyed by people in one country and another and can be used to distinguish between ethics, values and beliefs between two countries. Smaller cultural distances promote information flow and experience, technology diffusion (Gao Jian and Yang Li, 2014) between parent and host markets, make coordination costs for additional costs lower (Jiang Guanhong, 2015), and uncertainty about foreign investment, so it help enterprises to develop OFDI.

Hypothesis 3: The cultural distance between China and the host country is inversely proportional to the OFDI of the manufacturing enterprises in Shandong Province to countries along " the Belt and Road".

\section{Institutional Differences}

Harsh institutional environments increase investment risk and cost, making it difficult to meet the expected return on investment (Blonigen, 2005). However, Chinese companies may also use the institutional deficiencies in host countries such as corruption and legal weaknesses to seek benefits (Kolstad and Wiig 2009), which means they have greater comparative advantage in the opaque institutional environment (Wang Yongqin et al., 2014). In addition, it is thought that the outward FDI 
behavior of Chinese enterprises shows obvious resource-seeking characteristics (Li and Zheng, 2012). the poor system quality of the host country will instead promote China's resource-seeking OFDI (Buckley et al., 2007).

Hypothesis 4: When the host country has abundant natural resources, its quality of the system is inversely proportional to the OFDI of the manufacturing enterprises in Shandong Province to countries along " the Belt and Road".

\section{Data Description and Model Settings}

\section{Variable Setting and Data Source}

\section{Dependent Variable}

Foreign Direct Investment (OFDI): This paper adopts the dummy variables of enterprises above designated size in Shandong Province during 2009-2013 for direct investment in countries along " the Belt and Road" as the dependent variable, that is, when a certain enterprise makes direct investment in direct investment in country $\mathrm{j}$ in year $\mathrm{t}$, we assign it as 1 , otherwise assignment is 0 . Data source is "List of Overseas Investment Enterprises (Institutions)" promulgated by the Foreign Economic Cooperation Department of the Chinese Ministry of Commerce.

\section{The Main Explanatory Variables}

Host Country Resources(NRj): Based on the treatment of Buckly (2007) and Jiang Guanhong and Jiang Dianchun (2012), the abundance of natural resources in the host country is measured by the percentage of fuel exports accounted for the percentage of merchandise exports plus ore and metal exports in commodity exports. The source of data is World Bank database.

The strategic assets of the host country (ipr, hc, rd, tech): With reference to the literature by Buckly (2007) and Qiu Licheng and Yang Debin (2015), we take the number of resident patents, colleges and universities enrollment rate, R \& D share of GDP and high-tech exports accounted for the proportion of total exports as the proxy variables of strategic assets of the host country, the above data are from the World Bank database.

Institutional Difference (PE): This paper measures the institutional environment of the host country from the perspective of institutional quality, and measure the institutional difference between China and other countries as the average of the six sub-indicators of the global governance indicators published by the World Bank. The larger the value, the better institutional quality compared to China.

Cultural Distance (CDI): Based on the Hofstede's cultural dimensions of rights distance, risk aversion, individualism and collectivism, male and female four-dimensional measurement indicators, this paper uses the Pythagorean Theorem weighted synthesis, calculate the comprehensive cultural distance indicators between China and "the Belt and Road" countries. Cultural distance data from the official website of Hofstede, calculated by the author; establishment of diplomatic relations from the official website of the People's Republic of China.

\section{Control Variables}

Host Country Market Size (GDPj) and Geographical distance (DIS): The larger the host country's market, the greater the average wealth of the business and the greater the amount of funds available for outward FDI. In this paper, the host country GDP is used as the proxy variable of the market size. The data source is the World Bank database. This article uses the geographic distance between Jinan and the capital of the host country multiplied by the mean value of the price of crude oil in West Texas Intermediate and that of British Brent in the current year to represent the distance factor, which makes this variable reflects the cost of investment.

Foreign Investment Openness (FDI) and Bilateral Trade Relations (EC): The annual openness of foreign investment expressed by the flow of FDI from host countries to GDP per year. The higher the figure, the higher the country's acceptance of OFDI. Data source is the World Bank database. 
Bilateral trade relations reflect the close trade and economic ties between the two countries, and the data are derived from the UN Comtrade database and calculated by the author.

Efficiency of the host country (rur, PGDPj): In previous studies, efficiency was usually expressed as the labor cost of the host country, ie, the average wage level. However, the rural population could be regarded as a potentially cheap labor force and as an alternative variable for labor costs. This paper selects the host country GDP per capita and rural population as the proportion of the total population as proxy variables of host country efficiency, the data source is the World Bank database.

The age of enterprises (firmage) and OFDI experience (firmever): The duration of establishment is expressed by the difference between the inspection period and the establishment of the enterprise. The source of the data is the database of China's industrial enterprises. In this paper, we set up the investment experience of the enterprise as dummy variable which whether the period from 1980 to the inspection period of direct investment in country $\mathrm{j}$, if there is investment, the value is 1 , otherwise, the value is 0, and the data source is "Foreign Investment Enterprise (Organization) Directory".

\section{Model Establishment}

In the study of the use of gravity model for OFDI location selection, the original gravitation model (Anderson, 1979) is usually properly warped, and the required research variables are added for testing. In this paper, based on the original gravitation model, the model is set as follows according to the research of Wei (2000), Di Mauro (2000), Jiang Guanhong and Jiang Dianchun (2012):

$$
\mathrm{OFDI}_{i j t}=\beta_{0}+\beta_{1} \operatorname{lnGDP_{it}}+\beta_{2} \operatorname{lnGDP_{jt}}+\beta_{3} \ln D I S_{i j t}+\beta_{4} \text { firmever }+\beta_{5} \text { firmage }+\sum_{n} \theta_{n} C_{j t}^{n}+\mu_{t}
$$

Among them, $C_{j t}^{n}$ is other observational variables including cultural distance, bilateral trade relations, host country's openness to foreign capital, resources, strategic assets, efficiency and political risk. Taking into account the dependent variable is a binary variable, the logit model is the most reasonable choice. In addition, in order to reduce heteroskedasticity, we study the robust standard error of clustering in model estimation and take natural logarithm of geographical distance, per capita GDP of two countries and host country.

\section{Empirical Analysis}

Before conducting the formal test, we observe the characteristics of each variable data and report the correlation coefficient matrix firstly, the test does not exist serious collinear problems, due to the word limit the specific results are not shown. Table 3 shows the logit regression results. Specifically, lnGDPi is basically significant at the level of $1 \%$ and the coefficient is positive, indicating that the expansion of the economic scale in Shandong Province provides financial support to enterprises in the province and helps enterprises to carry out OFDI in " the Belt and Road" countries. LnGDPj's coefficients in the model are positive but not significant, indicating that the market size of the countries along the region has little effect on the OFDI of manufacturing enterprises in Shandong Province, that is, the motivation for the market is not obvious. LnDIS passes the test of $5 \%$ or $1 \%$ significance level and the coefficient is negative, indicating that as geographic distance increases, shipping costs increase, manufacturing enterprises in Shandong Province to reduce the possibility of OFDI, which also agrees with the actual situation that enterprises in Shandong Province's OFDI more concentrated in Southeast Asia. Firmever's coefficient is positive and significant at the level of 1\%, indicating that the business investment experience has a significant positive impact on investment behavior for future investment and gain experience to establish the necessary cooperative relations, thereby reducing the cost of the investment in the future. Firmage is not significant and the coefficient is positive, proving the positive correlation between the establishment time of the enterprise and the foreign investment. CDI passed the significance test of $1 \%$ level and the coefficient is negative, indicating that the smaller the national cultural distance, the higher the cultural co-integration, the more favorable it is for the Shandong provincial enterprises to reduce the investment cost. FDI and EC are positive but not significant, indicating that bilateral trade relations and the degree of openness of foreign capital in host countries are both positively related to OFDI in Shandong Province. In addition to model (6), NRj is significant at a level of $5 \%$ or $1 \%$ and the coefficient is positive, 
indicating that OFDI of manufacturing enterprises in Shandong Province in " the Belt and Road" countries has a strong motivation of resource seeking.

Afterwards, some variables were added to the model one by one. It can be observed that PE is not significant when tested individually, while when we add PENRj, which is the interaction between institutional distance and natural resources, is significant at $10 \%$ level, indicating that OFDI in Shandong Province is more suitable for poor systems Environment, but the system is inferior to the home country is not the cause of direct investment in Shandong along " the Belt and Road" countries, only in the countries which have rich natural resources, the premise of the manufacturing enterprises in Shandong Province will consider investment on it. The ipr, hc, rd and tech coefficients are both positive but only the proportion of research and development in GDP and the number of resident patents is significant at the level of $5 \%$ and $10 \%$, respectively. This shows that there is a strategic resource seeking motivation for Shandong Province enterprises' OFDI in " the Belt and Road" countries. The coefficient of rur is positive and lnPGDPj is negative but not significant, which means that the countries along the region with potential labor force and low labor cost have an uncertain impact on OFDI, and there is no obvious motivation of efficiency seeking.

Since most of the countries along " the Belt and Road" are developing countries, and most of OFDI in the country along the region also flows to developing countries, it is reasonable and valid to select samples from developing countries for robustness. Because the word limit does not show, compared with the full sample test, the significance, symbols and coefficients of all the variables in the sub-sample test are basically the same, proving that the result of the full sample test is not an accidental phenomenon. 
Table 1 Full sample test

\begin{tabular}{|c|c|c|c|c|c|c|c|c|c|}
\hline & (1) & (2) & (3) & (4) & (5) & (6) & (7) & (8) & (9) \\
\hline $\begin{array}{l}\text { VARIABLE } \\
\mathrm{S}\end{array}$ & OFDI & OFDI & OFDI & OFDI & OFDI & OFDI & OFDI & OFDI & OFDI \\
\hline \multirow[t]{2}{*}{ lnGDPi } & $\begin{array}{l}5.212^{* *} \\
*\end{array}$ & $\begin{array}{l}5.320^{* *} \\
*\end{array}$ & $\begin{array}{l}5.194 * * \\
*\end{array}$ & $6.381 * * *$ & $\begin{array}{l}5.433 * * \\
*\end{array}$ & $3.147^{* *}$ & $\begin{array}{l}5.402^{* *} \\
*\end{array}$ & $\begin{array}{l}5.198 * * \\
*\end{array}$ & $\begin{array}{l}5.222 * * \\
*\end{array}$ \\
\hline & $(1.153)$ & $(1.148)$ & $(1.130)$ & $(1.371)$ & $(1.237)$ & $(1.265)$ & $(1.215)$ & $(1.164)$ & $(1.158)$ \\
\hline \multirow[t]{2}{*}{$\operatorname{lnGDPj}$} & 0.0730 & 0.0699 & 0.130 & 0.334 & 0.135 & 0.307 & 0.0768 & 0.133 & 0.0952 \\
\hline & $(0.229)$ & $(0.236)$ & $(0.306)$ & $(0.367)$ & $(0.238)$ & $(0.316)$ & $(0.224)$ & $(0.227)$ & $(0.238)$ \\
\hline \multirow[t]{2}{*}{$\operatorname{lnDIS}$} & $-1.762^{* *}$ & $-1.918^{* *}$ & $\begin{array}{l}-2.227^{* *} \\
*\end{array}$ & $-2.986^{* *}$ & $\begin{array}{l}-1.892^{* *} \\
*\end{array}$ & -0.552 & $\begin{array}{l}-2.002^{* *} \\
*\end{array}$ & $-1.636^{* *}$ & $-1.684^{* *}$ \\
\hline & $(0.721)$ & $(0.751)$ & $(0.747)$ & (1.177) & $(0.670)$ & $(0.864)$ & $(0.775)$ & $(0.756)$ & $(0.764)$ \\
\hline \multirow[t]{2}{*}{ firmever } & $\begin{array}{l}3.394^{* * *} \\
*\end{array}$ & $\begin{array}{l}3.403^{* *} \\
*\end{array}$ & $\begin{array}{l}3.387^{* *} \\
*\end{array}$ & $3.736 * * *$ & $\begin{array}{l}3.546^{* *} \\
*\end{array}$ & $\begin{array}{l}3.411^{* *} \\
*\end{array}$ & $\begin{array}{l}3.401^{* * *} \\
*\end{array}$ & $\begin{array}{l}3.420 * * \\
*\end{array}$ & $\begin{array}{l}3.383^{* *} \\
*\end{array}$ \\
\hline & $(0.556)$ & $(0.555)$ & $(0.544)$ & $(0.593)$ & $(0.688)$ & $(0.629)$ & $(0.557)$ & $(0.567)$ & $(0.554)$ \\
\hline \multirow[t]{2}{*}{ firmage } & 0.0103 & 0.00848 & 0.00840 & 0.0119 & $\begin{array}{l}-0.00044 \\
0\end{array}$ & $\begin{array}{l}0.0254^{*} \\
*\end{array}$ & 0.0137 & 0.0131 & 0.0117 \\
\hline & $(0.0108)$ & $(0.0115)$ & $(0.0106)$ & $(0.0135)$ & $(0.0139)$ & $(0.0100)$ & $(0.0109)$ & $(0.0117)$ & $(0.0115)$ \\
\hline \multirow[t]{2}{*}{ CDI } & $\begin{array}{l}-0.528 * * \\
*\end{array}$ & $\begin{array}{l}-0.578^{* *} \\
*\end{array}$ & $\begin{array}{l}-0.854 * * \\
*\end{array}$ & $\begin{array}{l}-1.100 * * \\
*\end{array}$ & $\begin{array}{l}-0.719 * * \\
*\end{array}$ & $\begin{array}{l}-0.632 * * \\
*\end{array}$ & $\begin{array}{l}-0.530 * * \\
*\end{array}$ & $\begin{array}{l}-0.559 * * \\
*\end{array}$ & $\begin{array}{l}-0.536 * * \\
*\end{array}$ \\
\hline & $(0.159)$ & $(0.179)$ & $(0.245)$ & $(0.366)$ & $(0.277)$ & $(0.203)$ & $(0.158)$ & $(0.161)$ & $(0.158)$ \\
\hline \multirow[t]{2}{*}{$\overline{\text { FDI }}$} & 0.0270 & $\begin{array}{l}0.00013 \\
0\end{array}$ & 0.0351 & $0.0391 *$ & 0.0712 & $\begin{array}{l}0.142 * * \\
*\end{array}$ & $0.0426^{*}$ & $0.0626^{*}$ & 0.0420 \\
\hline & $(0.0167)$ & $(0.0366)$ & $(0.0373)$ & $(0.0216)$ & $(0.136)$ & $(0.0524)$ & $(0.0236)$ & $(0.0370)$ & $(0.0351)$ \\
\hline \multirow[t]{2}{*}{ EC } & 0.779 & 0.984 & 1.865 & 0.978 & 1.258 & 1.848 & 1.032 & 0.869 & 0.757 \\
\hline & $(1.258)$ & (1.422) & (1.675) & $(1.414)$ & (1.191) & $(1.854)$ & (1.188) & (1.231) & $(1.253)$ \\
\hline \multirow[t]{2}{*}{ NRj } & $\begin{array}{l}2.039 * * \\
* \\
\end{array}$ & $\begin{array}{l}2.232^{* *} \\
* \\
\end{array}$ & $\begin{array}{l}4.225^{* *} \\
* \\
\end{array}$ & $3.129 * * *$ & $\begin{array}{l}2.155^{* *} \\
* \\
\end{array}$ & 0.988 & $\begin{array}{l}2.104^{* *} \\
* \\
\end{array}$ & $\begin{array}{l}2.552 * * \\
* \\
\end{array}$ & $2.230^{* *}$ \\
\hline & $(0.775)$ & $(0.785)$ & $(1.350)$ & $(1.038)$ & $(0.820)$ & $(0.933)$ & $(0.778)$ & $(0.911)$ & $(0.912)$ \\
\hline \multirow[t]{2}{*}{ PE } & & -0.277 & -1.325 & & & & & & \\
\hline & & $(0.348)$ & $(0.549)$ & & & & & & \\
\hline \multirow[t]{2}{*}{ PENRj } & & & $-3.974 *$ & & & & & & \\
\hline & & & (2.298) & & & & & & \\
\hline \multirow[t]{2}{*}{ ipr } & & & & $\begin{array}{l}8.57 e-05 \\
*\end{array}$ & & & & & \\
\hline & & & & $\begin{array}{l}(4.60 \mathrm{e}-0 \\
5)\end{array}$ & & & & & \\
\hline \multirow[t]{2}{*}{ hc } & & & & & 0.0137 & & & & \\
\hline & & & & & $(0.0147)$ & & & & \\
\hline \multirow[t]{2}{*}{$\mathrm{rd}$} & & & & & & $1.365^{* *}$ & & & \\
\hline & & & & & & $(0.555)$ & & & \\
\hline \multirow[t]{2}{*}{ tech } & & & & & & & 0.00916 & & \\
\hline & & & & & & & $(0.0103)$ & & \\
\hline \multirow[t]{2}{*}{ rur } & & & & & & & & 0.0129 & \\
\hline & & & & & & & & $(0.0122)$ & \\
\hline \multirow[t]{2}{*}{ lnPGDPj } & & & & & & & & & -0.0992 \\
\hline & & & & & & & & & $(0.210)$ \\
\hline \multirow[t]{2}{*}{ Constant } & $\begin{array}{l}-107.4 * * \\
*\end{array}$ & $\begin{array}{l}-108.1^{* *} \\
*\end{array}$ & $\begin{array}{l}-106.6^{* *} \\
*\end{array}$ & $\begin{array}{l}-132.2 * * \\
*\end{array}$ & $\begin{array}{l}-109.2^{* *} \\
*\end{array}$ & $\begin{array}{l}-80.79 * * \\
*\end{array}$ & $\begin{array}{l}-108.8^{* *} \\
*\end{array}$ & $\begin{array}{l}-107.9 * * \\
*\end{array}$ & $\begin{array}{l}-107.4^{* *} \\
*\end{array}$ \\
\hline & (22.67) & $(22.49)$ & (22.15) & $(26.44)$ & (25.67) & $(25.54)$ & (23.15) & $(23.00)$ & (22.75) \\
\hline $\begin{array}{l}\text { Observation } \\
\text { s }\end{array}$ & 403 & 403 & 403 & 374 & 317 & 302 & 403 & 403 & 403 \\
\hline
\end{tabular}

Robust standard errors in parentheses $* * * \mathrm{p}<0.01,{ }^{* *} \mathrm{p}<0.05$, ${ }^{*} \mathrm{p}<0.1$ 


\section{Conclusions and Policy Recommendations}

In this paper, we use logit analysis of the panel data of the direct investment of manufacturing enterprises above designated size in Shandong Province in countries along " the Belt and Road" from 2009 to 2013, test the location selection and influencing factors of manufacturing enterprises above designated size in Shandong Province for direct investment in countries along " the Belt and Road". The results show that there is a positive trend for the Shandong Province above-scale manufacturing enterprises' OFDI in "Belt and Road" countries as a result of the economic scale in Shandong Province, the host country's natural resources, the number of resident's patents, the R \& D share in GDP and the investment experience of enterprises, but cultural distance has a negative impact. In addition, countries with poor systems can promote OFDI in Shandong Province only when they have rich natural resources.

With the continuous development of " the Belt and Road " Initiative, the ties with the countries along the route will continue to increase. In the future, more enterprises in Shandong Province will make direct investments in the countries in the region. Therefore, the research in this paper has realistic reference significance to enterprises in Shandong Province for direct investment in "Belt and Road" countries, and has some enlightenments to the government and enterprises in Shandong Province as follows: (1) The Shandong provincial government should respond positively to " the Belt and Road " Initiative and further strengthen exchanges and cooperation with countries along the region, establish an information platform and step up guidance to foreign investment by enterprises. (2) The enterprises should actively face the OFDI and take the market as the guidance, and make investment decisions after examining a host of comprehensive conditions such as the host country's resource reserve, institutional environment and labor cost, accumulating abundant experience for future overseas investment. (3) We should learn to understand the culture and customs of the host country, cultivate internationalized and professional communicative talents, and reduce transaction costs and conflicts caused by excessive cultural differences.

\section{References}

[1] P. Deng, Outward Investment by Chinese MNCs: Motivations and Implications, J. Business Horizons. 3 (2003) 8-16.

[2] B. A. Blonigen, A Review of the Empirical Literature on FDI Determinants, J. Atlantic Economic Journal. 4 (2005) 383-403.

[3] I. Kolstad, ,A. Wiig, What Detemines Chinese Outward FDI, CMI Working Papers, 3 (2009) .

[4] P. J. Buckley, ,L. J. Clegg, A. R. Cross, ,X. Liu, H. Voss, P. Zhang, The Determinants of Chinese Outward Foreign Investment, J. Journal of International Business Studies, 38 (2007) 499-518.

[5] J. E. Anderson, A Theoretical Foundation for the Gravity Equation, J. The American Economic Review, 1 (1979) 106-116.

[6] M. F. Di, The Impact of Wconomic Integration on FDI and Exports: A Gravity Approach, CEPS Workingpaper Document, (2000). 